\title{
Hunger: Testing Testimonial Limits in the Gray Zone
}

\author{
Björn Krondorfer
}

Martin-Springer Institute, Northern Arizona University, Flagstaff, AZ 86011, USA; bjorn.krondorfer@nau.edu

\section{check for}

updates

Citation: Krondorfer, Björn. 2021. Hunger: Testing Testimonial Limits in the Gray Zone. Humanities 10: 21. https://doi.org/10.3390/h10010021

Received: 24 December 2020 Accepted: 24 January 2021 Published: 27 January 2021

Publisher's Note: MDPI stays neutral with regard to jurisdictional claims in published maps and institutional affiliations.

Copyright: (C) 2021 by the author. Licensee MDPI, Basel, Switzerland. This article is an open access article distributed under the terms and conditions of the Creative Commons Attribution (CC BY) license (https:// creativecommons.org/licenses/by/ $4.0 /)$.

\begin{abstract}
Literary descriptions of the multitude of experiences during the Holocaust and World War II face the dilemma of the (non)representability of extreme duress. This article delves into the testimonial remnants of two men in the gray zone of complicity: Eliezer Gruenbaum's harrowing recollections of starving prisoners in Birkenau, and Konrad Jarausch's chronicling of his burgeoning despair over his inability to feed Soviet POWs in the winter of 1941. Both men testify to the devastating effects of hunger (due to deliberate starvation policies) from positions that implicate them as complicit observers. This article employs Naomi Mandel's idea of complicity as the condition for responsibility, Jill Stauffer's ethical loneliness, and Primo Levi's gray zone to make interpretive suggestions for understanding their testimonies.
\end{abstract}

Keywords: Holocaust; World War II; hunger; gray zone; complicity; witnessing

In his well-known chapter on "the Gray zone," Auschwitz survivor Primo Levi reflects on the conditions of the concentration camps that created groups of prisoners with certain privileges in exchange for performing tasks that maintained order according to the wishes of the German camp administration and Nazi guards. ${ }^{1}$ While power and complicity are the core poles around which Levi organizes his thoughts on the gray zone-reflections born out of a survivor's agony of having witnessed the amorality and destructiveness of both-another theme pervades his chapter: hunger. Though not dwelled on extensively, extreme hunger appears repeatedly as the cause of and driving force for camp prisoners' acts and choices, including becoming prison functionaries doing the bidding of the Nazis. "Whoever belonged to this group," Levi writes, "was privileged only to the extent that-but at what cost! - he had enough to eat" (Levi 1989, p. 50). Survival and food were inextricably linked within a system of total power. Access to food to secure survival (or, at least, to live a little longer) came at the cost of complicity.

Whether those who are not hungry understand the ferocious force of starvation that throbs steadily, but nearly inaudibly, in Levi's text points to the limits of testimony, to whether or not there remains something unsayable and unrepresentable in testimonies about human-made calamities. ${ }^{2}$ Fact-driven definitions might be informative-_"starvation is defined as a severe deficiency in caloric energy intake needed to maintain human life [and] can cause permanent organ damage and eventually, death" ${ }^{3}$ — but they do not convey a starving person's utter despair to the point of loss of physical and mental control. Extreme hunger, like all human conditions at the edge of extremity, defies a language of recognition. A diary entry of eighteen-year-old Nina Mervol'f about her father's final stage of distrofia during the Leningrad siege might help us to recognize that extreme hunger obliterates a person's moral core. ${ }^{4}$ During the 872 day siege of Leningrad by German forces during

1 The chapter on "the gray zone" is included in Levi's The Drowned and the Saved (Levi 1989). For further discussion of privileged Jews and the gray zone, see Petropolous and Roth (2005), Brown (2013), and Lee (2016).

2 For a critique of banning the articulation of experiences of severe violence and trauma into the realm of the "unspeakable" or "unsayable," see Agamben (1999) and Mandel (2006). For a discussion of Agamben and Mandel, see Glowacka (2012, pp. 11-13).

3 https://www.disabled-world.com/fitness/starving.php (accessed 15 December 2020).

4 On the usage and meaning of distrofia in Leningrad, see Peri (2017). It referred first and foremost to nutritional dystrophy but was later expanded by diarists to include "dystrophy of the mind" and "moral dystrophy." Distrofia was so closely associated with the siege of Leningrad that Gulag prisoners suffering from similar symptoms called it the "Leningrad illness" (pp. 180-91). 
World War II, which took the lives of 800,000 Soviet civilians mostly due to starvation, people recorded in diaries the breakdown of social life, of family, and eventually of the body itself. Distrofia described those who suffered from symptoms of extreme hunger: first, weight loss, hunger pangs, and muscle pain; then fatigue, severe weight loss, low heart rate and low body temperature; in the terminal stage, body swellings and wasting away in bed (see Peri 2017, p. 182). Mervol'f notes in her diary:

He is completely withered, his face is yellow and puffy, and his eyes are glazed ... He has become deranged ... indifferent to everything. Or he begins to cry or scream from hunger and [that] he is prepared to eat himself ... This is not Papa, it is simply not him — this is a dirty, lice-infested, half insane person, almost not even a person. (Peri 2017, p. 196)

As a reader or listener, we would have to slow down, invest in the text, and engage our imagination if we genuinely tried to recognize the effects of extreme hunger on the body, the mind, and intimate social relationships. Often, we do not. Though there is epistemic legitimacy to argue that there are limits to the literary representability of living (and dying) under extreme conditions, this article is not about the limits of language. Rather, it is about the limits of testimony in the gray zone of complicity.

\section{Language and Complicity}

The assertion that we may not grasp the extensiveness of extreme hunger is no excuse not to practice an empathy that grasps enough to unsettle us. ${ }^{5}$ In her book Against the Unspeakable, Naomi Mandel suggests eschewing the idiom of the "unspeakable" and replacing it with the term complicity. For her, complicity does not denote culpability or collaboration but a way of engaging with texts that testify to "atrocity, horror, trauma, and pain" (Mandel 2006, pp. 4, 208). Listening and responding to such texts require of us to become, to some degree, complicit with the violence we encounter. Understood thus, complicity is aligned with responsibility and becomes the "condition of possibility for ethical engagement" (22). For Mandel, complicity indicates a horizon of perceiving ourselves intimately involved in our attempts at recognizing humanity under extreme conditions, something that Michael Rothberg might call the "implicated subject" (Rothberg 2019).

For those who survived or directly witnessed starvation, a gap will always exist between the experience of the traumatizing event itself and attempts at a narrative retellingand this unbridgeable gap can, at times, leave the survivor in a state of "ethical loneliness" (Stauffer 2015) from which the only escape is to take one's life. Primo Levi was among them. ${ }^{6}$ This gap, however, does not abdicate our responsibility as outsiders to listen to and acknowledge the distress of people who lived through hardship. Hiding behind a defense of the "unspeakable" can become a mental ploy not to engage with the abject suffering caused by other human beings. As we read, assess, or judge literary representations of severe duress and assault, we become implicated and complicit, that is, we begin to engage ethically the complexity of life in extremis.

In this article, I will look at the testimonial remnants of two men who were complicit in the machinery of lethal starvation - two men struggling to make sense of their actions in the 1940s regarding the feeding of camp inmates. Adding another layer of ethical complexity, the examples take us to two different types of camps in which each man occupies a position of relative power, though in quite distinct ways. Konrad Jarausch, a German soldier in the rank of a reserve officer in the East, was put in charge of feeding Russians in a POW camp. Eliezer Gruenbaum, a Polish Jew from Warsaw, became a kapo in the death camp of Auschwitz-Birkenau overseeing the daily distribution of the meager soup ration. Jarausch was a Protestant national patriot who regarded Nazism as a chance to renew the nation and the church, although he refused to join the Nazi Party. In 1941, at the age of 41, he

5 On the productive power of empathy to unsettle us, see Krondorfer (2020).

6 In addition to Levi, two other well-known survivors took their own lives, Jean Améry and Paul Celan. All three were prolific writers after 1945 , testifying in great length, detail, and eloquence to the (im)possibility of conveying their experiences during the Holocaust. 
supervised the field kitchens of Dulag 203 (Durchgangslager) in Kochanovo and Kritschev (Belarus) near the Eastern front. ${ }^{7}$ Gruenbaum was a Communist in prewar Poland, who, at twenty-one years of age, was imprisoned and tortured by the Polish government as an anti-nationalist revolutionary. From 1942 to 1944, in his early 30s, he was a prison functionary in Birkenau in charge of fellow Jews. Born in 1900 and 1908, respectively, neither man reached the age of 45 .

Konrad Jarausch left over 350 letters that he wrote as a soldier near the battlefields in the East, mostly to his wife but also to friends. The letters were posthumously edited and published in German and later in English as Reluctant Accomplice by his son Konrad H. Jarausch, a German-American historian. ${ }^{8}$ Eliezer Gruenbaum wrote a diary, a segment of which was posthumously published in Hebrew in the Scrolls of Fire (Gevilei Esh) and partially translated into English (Friling 2014; Glasner-Heled and Bar-On 2009). Their testimonial fragments are stories of complicity - a complicity that connects them in terms of the moral quandary of making decisions under extreme circumstances but divides them in terms of the writers' respective status as accomplice and victim. Not only do we enter the gray zone of individual behavior during World War II and the Holocaust, we also enter the gray zone of ethically assessing the testimonies they left behind.

\section{Konrad Jarausch: Between Protestantism and Militarism}

Approximately three weeks after the German attack on the Soviet Union on 22 June 1941, Konrad Jarausch was sent East to guard thousands of Soviet soldiers captured during the rapid advance of the German troops. By this point, Jarausch was considered essential personnel because he had already served in Poland as a POW guard and as a trainer for new German recruits since the beginning of the war in September 1939. Many of his letters speak to his experiences during these two years in Poland. The topics range from his amazement of German military success to meaningless paperwork, from comradeship to guarding Polish POWs, from describing a visit to the Lodz ghetto to questioning the meaning of war, God, and the maltreatment of Jews. "I'm continually confronted with the question on what kind of soldiers we are or can be," he writes in a letter from Poland on 19 November 1939 after briefly commenting on the situation of Jews in the Kalisch district (Jarausch 2011, p. 109).

Jarausch belonged to the generational cohort of the 1918ers. ${ }^{9}$ This generation of men was marked by the experience of World War I, the perceived national humiliation of 1918, and an underdeveloped appreciation of democratic governance. His age cohort generally lacked loyalty to the Weimar Republic and perceived the rise of Nazism and Hitler as an opportunity for a strong nation and unified Volk (ethnic people). Jarausch's embrace of Nazism, however, was tempered by his attachment to Christianity through Bible study, minoring in Protestant theology, and becoming a religion teacher. Lotte, his future wife, also studied religion under a Lutheran theologian. Although German Protestantism sought a unified völkisch nation, Christianity also allowed Jarausch a critical distance to, what he called, the error of the "deification of the Volk" (Jarausch 2011, p. 21). An absolutist state, he warned in 1938, could be a threat to the church and to Christ's message (22). This background helps to understand Jarausch's war letters that testify to internal conflicts regarding military service. Conscripted in 1939, he was fascinated by the "adventure of war," yet irate about the emptiness and crudeness of military routine, particularly his comrades' drinking, cursing, and whoring (23-24).

7 Dulag was an abbreviation for the German word Durchgangslager. These were transit camps through which POWs passed for processing. They were spread across Germany and Nazi-occupied Europe. While Allied prisoners of war were treated adequately in camps, for Soviet soldiers, the Dulags and POW camps were places of intentional death-by-attrition policies.

8 A reader might be confused about father and son sharing the same name: Konrad H. Jarausch is the son who published the letters of his father, Konrad Jarausch. The longer German version appeared in 2008, "Das stille Sterben ... ": Feldpostbriefe von Konrad Jarausch aus Polen und Russland; the English version, with a revised introduction, in 2011, Reluctant Accomplice: A Wehrmacht Soldier's Letters from the Eastern Front.

9 For a study of generational cohorts in twentieth-century Germany, especially as regards the autobiographical writings of German Protestant theologians, see Krondorfer (2006; regarding the 1918er cohort, pp. 34-39, 46-49). 
The situation changed and intensified with the invasion of the Soviet Union in 1941. Jarausch's son summarizes it in these words:

The invasion of Russia also clarified Konrad Jarausch's military future, since he was sent to Dulag 203 in the central front on August 11 ... [as an] experienced personnel to guard the hundreds of thousands of Soviet prisoners ... The Durchgangslager were the initial reception camps that operated fairly closely behind the front in order "to hold and guard" the prisoners who had been captured in the fighting, and to sort them for shipment as laborers to Germany or killing by the SS as ideological enemies and racial inferiors. (Jarausch 2011, p. 239)

Among other duties, Jarausch was now put in charge of field kitchens to feed thousands of captured Soviet soldiers in the Dulag. Given the never-sufficient supplies, his letters attest in heart-wrenching detail the rush for food among starving prisoners in the cramped and unsanitary conditions of two camps, Kochanovo and Kritschev in Belarus.

\section{Eliezer Gruenbaum: Between Communism and Survival}

Before arriving in Auschwitz Birkenau as an inmate in the summer of 1942, Gruenbaum had been a Communist activist in Poland and in France. Born in Warsaw, he grew up in a family with strong non-religious Zionist convictions. His father Yitzhak represented a faction of Poland's Jews in the Polish parliament and, as a "uncompromising and proud Zionist leader" (Glasner-Heled and Bar-On 2009, p. 2), hoped to unite Jews and gain minority rights concession from the Polish government. Disappointed by political developments, Yitzhak and his family left Europe and arrived in Palestine in 1933, where Yitzhak soon rose to prominence in Yishuv politics—-the settlement of Jews in Palestine that would later become Israel. His son Eliezer, however, did not join them and remained in Europe. Eliezer Gruenbaum had earlier rejected his father's Zionism and allied himself with the Communist Party. After his release from Polish prison for anti-nationalist activities, he went to Paris to rejoin Communist groups, fought in the Spanish Civil War, then returned to the underground in Paris where he was arrested in April 1941 during a roundup by the French police. From there, he was transported to Auschwitz. ${ }^{10}$

Throughout this time, Gruenbaum proved to be strong willed and hard headed: he organized people, redressed injustices of nationalist and fascist governments, and did not shy away from defying orders from political groups he was affiliated with. He opposed, for example, escape plans from the French prison camp of Beaune-la-Rolande in spring 1942, although he was instructed by the Communist party to organize such prison breaks. He objected on the grounds that only the strongest would be able to escape, "leaving behind the weak without leaders" (Friling 2014, p. 29).

Gruenbaum became Häftling 43057 in Auschwitz-Birkenau, where he stayed for approximately twenty months before being transferred in 1944 to the coal mines of Jawischowitz, one of the Auschwitz subcamps. ${ }^{11}$ Jawischowitz had such grim conditions that prisoners quickly turned into muselmen, men who had given up their will to live often due to chronic starvation and exhaustion. ${ }^{12}$ Gruenbaum survived Jawischowitz as well. With the advancing Soviet army in January 1945, the remaining prisoners, Gruenbaum among them, were sent in coal cars and on foot to Mauthausen, then Buchenwald, where he was finally liberated.

Gruenbaum's survival reads like a heroic story of resilience and resistance were it not for the many accusations by fellow prisoners that he had brutalized and betrayed them in his position as camp functionary. According to Gruenbaum, he became a kapo only reluctantly, a position often assigned by the SS to supervise forced labor or carry out administrative tasks. He insisted that he remained active in the camp's underground

10 For a detailed historical study on Eliezer Gruenbaum and his family, see Friling (2014).

11 For more information on Jawischowitz, see http:/ / auschwitz.org/en/history/auschwitz-sub-camps/jawischowitz/ (accessed 15 December 2020).

12 There is extensive literature on the muselmen. For recent research, see Becker and Bock (2020). 
resistance. Beatings, he claimed, were simply part of the tasks of a kapo, for otherwise the SS or criminal overseers would administer even harsher penalties. Some survivors and comrades from the underground supported Gruenbaum's version, others accused him of collaboration and unnecessarily brutal beatings. Already in Birkenau, fellow prisoners opposed and avoided him. Suspicion followed Gruenbaum when he was transferred to the labor camp of Jawischowitz, where, upon his arrival, he tried to connect to the underground. An improvised trial among prisoners took place against him when he got to Buchenwald in 1945. Though the prisoners' committee acquitted Gruenbaum of the charge of unprovoked beatings, after liberation he had to defend himself against incriminations, rumors, and formal and informal trials for the rest of his life in France, Poland, and Israel. ${ }^{13}$

\section{Feeding the Starving}

The first entry about his kitchen and food distribution duties appears more like an aside. On 16 August 1941, Jarausch writes about the camp in Kochanovo: "[The major] sent me straight away to the camp kitchen ... There are only six hundred prisoners here, and everything is set up and practically runs itself" (Jarausch 2011, p. 255). A few lines later, he comments on the 300 grams of chocolate, cigarettes, and alcohol he received to enjoy a social evening. This situation would rapidly change in the next few weeks. A non-dated entry from later in August signals the disaster that is to come:

[W]e had quite a downpour. The creek flooded and the meadows were covered in water. At the same time, we received some 10,000 to 12,000 prisoners. They had marched thirty to forty $\mathrm{km}$ from the front; they were soaked; they had gone days without food and had eaten green sheaves of grain ... Their hunger drove them to the kitchens. Shots were fired to keep them in order. Some (not many) were killed. Others rolled around in the mud, howling from their hunger pains. The next morning several corpses were pulled out of the mud; only their legs or heads stuck up out of the mess. (Jarausch 2011, p. 261)

From then on, Jarausch's letters return time and again to the prisoners. August 18/19: "I can't even begin to describe the impressions that these starving, filthy figures make when they stand with tin cans in the soup lines" (Jarausch 2011, p. 265). August 28: "[P] leople with special privileges come to receive their extra rations of bread-sentries, cooks, translators, officers, carpenters, etc. Outside, the prisoners are fighting over their soup rations. Things are pretty rough and ready, but they are all too human" (270). September 1: "We had 12,300 prisoners in our camp during the last days ... One is constantly surrounded by the stench and the cries, beset by incessant pleading" (274). On November 1, already at the new camp in Kritschev, he writes: "One becomes rather numb to things. Because I now have to oversee the provision of 17,000 to 18,000 warm meals" (313). A particularly harrowing letter is dated November 12: "When they come to get their food and are frozen stiff from the cold ... they stagger, fall over, and expire right at our feet. We discovered another case of cannibalism today. Yet the corpses, when they are carried out without clothes to the graves, are scrawny like gothic figures of Christ, frozen stiff"' (pp. 324-25).

Starving prisoners is not the only theme in his letters. Jarausch also reports on his readings during free time, on conversations he has with imprisoned Russian artists and intellectuals (he even takes Russian language sessions), his doubts about the war, and about destroyed villages and abandoned churches. But nothing seems to haunt him more during these months than the hungry POWs he needs to feed. The annihilation of Jews makes only fleeting appearances in his letters, perhaps because of military censorship. September 30: "Among the ruins there were printed and handwritten books in Hebrew" (298); October 12: "The SS are cleaning out [the area] in terrible fashion" (306); November 7: "Jews barefoot in the snow" (319). What truly troubles him, however, is the "infinite suffering" of the starving POWs (327).

13 For a detailed study of the accusations against Gruenbaum and his defense, see Friling (2014). 
Though Jarausch wavers on the question of the legitimacy of the war against Bolshevism, he does not consider Russians to be Untermenschen and he laments their inhumane treatment. In the four months between August and December 1941, he increasingly reaches out to Russians, befriends them (sometimes only for a short time), and, in the process, humanizes them in his letters. "When one sees a man crying because a comrade who was supposed to share his portion of soup has already eaten it," he writes on October 15 , "one can see how redemption in the afterlife must overcome even this misery" (307). Referencing Christian values, he grapples with the rationale and horrors of the war he is part of. "I cannot spot a single enemy amid the millions of Russians," he writes on November 25 (333).

Do these entries render Jarausch less culpable of and less complicit in the atrocious war in the East? He does not parrot the Nazi propaganda of a Bolshevik-Jewish race that must be eliminated. Instead, he speaks of his interactions with prisoners through a humanizing lens of religious empathetic engagement. "One tries to help," he writes on November 14. "We've just been thrown into this situation, incapable of doing anything other than our limited duty" (325).

In the context of an eliminationist war, however, it is impossible not to be implicated in what one also bemoans. Interactions with prisoners are distorted actions. No matter personal intentions, the situation created toxins that may have gone unnoticed because of one's position of relative power. When, for example, Jarausch expresses concern for his Russian language teacher whose "spirit has been broken," it is not clear whether the concern is for the teacher or for his lessons: "He has stomach troubles and we aren't making any progress in our lessons." In the same breath, he continues: "In the middle of this-the rags, the stench, and disease-we have to keep our heads up and act like we're superior and then every now and then play a more human and empathetic role" (314).

Placed in an impossible situation-a situation that overwhelms a person's physical stamina and moral compass-perhaps the best a person can do is "playing" an empathetic role. The tasks into which soldiers were pressed by circumstances over which they had limited control made Jarausch do things he otherwise would have shunned. In such a situation, feigned empathy is not the worst moral choice. Shall we, therefore, conceive of Jarausch as a genteel force within a vulgar environment, as someone who did as much good as possible under these circumstances? Or did his duties in Dulag 203 require other actions as well?

The literary and moral merit of Jarausch's letters lies in their immediacy. His prose speaks to us directly; he had no chance to adjust retrospectively his narrative to a changing Zeitgeist. Occasionally, Jarausch mentions the violence that accompanied the distribution of food. Cautious at first, he writes on September 1: "One is constantly surrounded by the stench and the cries, beset by incessant pleading. To keep things going overall, one sometimes has to be hard-nosed toward individuals ... They fight with one another and that rubs off on us; above all there is a constant pressure to economize. We can't satisfy the prisoner's hunger" (274). As a reader, we may wonder what exactly the term "hard-nosed" implies and whether Jarausch himself participated in forceful behavior. On October 25, the issue of enforcement violence reappears. The situation in the camp had temporarily eased because of a reduction in the prison population from 20,000 to 6000 . "I no longer have to play the policeman and don't need to beat anyone down with a nightstick or have them shot. Still, things are harrowing enough" (310). One month later, on November 24, with all defensive semantics falling to the wayside, he writes to a friend:

I had to feed 16,000 to 18,000 men during many days, at least as far as that was possible. We have five Germans in the administration and the kitchens and eight guards. You can imagine that we had to beat and shoot. During such times the kitchen administration doesn't resemble anything in civilian life. One beats and shoots to create some kind of order around kitchens. (Jarausch 2011, p. 331)

Within a system designed for starvation (and annihilation), Jarausch did commit acts of violence. 
Let us now turn our attention to Eliezer Gruenbaum. The publicly available segments of his diary, translated from Hebrew as either In the Death Zone or In the Courtyards of Death, open with the following paragraph: ${ }^{14}$

All of us must have seen, at the cinema, the scene of a passenger ship sinking at sea. There is panic on deck; women and children first; a crowd of people mad with fear, pouncing on lifeboats; the ability to think vanishes. Only one desire remains-to live! And standing by the lifeboats are officers, pistols in hand, holding back the mob, and shots are heard. (Friling 2014, p. 177)

In this opening passage of Gruenbaum's reckoning with his past, his will to survive is a barely concealed leitmotif. He draws a parallel between officers on a sinking ship who threaten violence to organize the survival of passengers and his position as a camp functionary in Birkenau. From there, Gruenbaum leads us straight into the heart of camp life: "And we, the officials, would stand by the cauldron of soup as if a fountain of life."15

A thousand people crazed with hunger, and not the hunger with which you are acquainted, that gnaws on your stomach. Camp hunger was different ... It did not just gnaw at the stomach, but the entire person, at all the thoughts and feelings of the person facing the peril of death by hunger ... Every person knew that they, too, were destined to die of hunger. Consequently, you had to eat, at all costs! (Glasner-Heled and Bar-On 2009, p. 55).

The scarcity of food makes the fear of becoming a muselman ever so present, a fear that Gruenbaum shares with all prisoners. "Anything but to be a muselman," he writes (Friling 2014, p. 177). He knew that anyone who had reached the stage of a muselman was destined to die. Gruenbaum recalls a moment when he, as kapo, had to collect people for work and an SS man ordered him to pick men from a group of "Muselmänner [who] lay, sat, and kneeled in the mud ... drained of all their strength" (179). Protesting that none of them could even move, the SS guard threw pieces of bread among them. "It's impossible to describe what happened then," Gruenbaum recalls. "Have you ever seen how one dying man strangles another dying man and tears from his mouth half-chewed bread mixed with spittle? I have seen it, and not just then" (179).

Like Jarausch, Gruenbaum is an astute observer and, at times, an empathetic witness. "Have you ever seen dying people, expiring with a happy smile on their faces when you put a chunk of bread in their hands that they no longer have the strength to lift to their mouths?" (Friling 2014, p. 179). On one occasion, prisoners waiting in line became a "raging mob," forcing the food dispensers to flee (it is not clear whether Gruenbaum is among those who escaped the mob). The kettles with soup were toppled. "People collected the spilled soup from the ground, in which hundreds of feet had stomped, and slurped it." One prisoner, who fell into a kettle, was dripping with soup when he emerged, "with pieces of potato and beet stuck to his coat .. 700 crazed people ran after him and licked the food off him" (178). On another occasion, Gruenbaum recalls how he "slapped the face of a young man" who had pushed his way to the front of the line. "He looked at me with such sorrow and despair, without anger or censor, that I did not know where to put myself. I poured soup into his bowl. His eyes shone with truly divine joy. But twenty empty bowls and twenty faces appeared before me. I placed the ladle in someone else's hand and fled" (Glasner-Heled and Bar-On 2009, pp. 6-7).

While Gruenbaum appears in this scene as an acting agent who has the power to slap a man in the face but also to pour soup, he says little about the few privileges he received as a kapo. Camp functionaries had access to food in ways ordinary prisoners did not.

14 The select diary entries were published in Hebrew as "BeHatzerot haMavet" in an anthology called Gevilei Esh (Scrolls of Fire) that memorialized fallen Israeli soldiers. I am relying on the slightly different English translations offered by Friling (2014, pp. 177-81), who translates the title as In the Death Zone, and Glasner-Heled and Bar-On (2009, pp. 5-14), who suggest the title In the Courtyards of Death.

15 I am quoting from two separate translations of the same paragraph. This opening sentence is in Friling (2014, p. 177), the longer quote in Glasner-Heled and Bar-On (2009, p. 5). 
Excruciating as the details are that Gruenbaum recalls, it is not his hunger. ${ }^{16}$ He describes the prisoners from the vantage point of the person behind the cauldron dispensing food, a position of relative power, just as in Jarausch's case. Gruenbaum looks at the lined-up prisoners in horror and with empathy and fear. Like Jarausch, his task was to figure out how to dispense the meager food rations. "I tried various methods," Gruenbaum writes. "I tried distributing in turn ... [or] to a list of young people ... I was unsuccessful." "Second helpings," he admits, "had to be distributed with a cane" (Glasner-Heled and Bar-On 2009, p. 6). Gruenbaum enforced order. Unlike German guards, he had no authority to have people shot, but he relied on his cane for beatings.

Intriguingly, the nationalist-leaning Protestant German reserve officer in the Dulag and the Communist Jewish kapo in Birkenau both reference the biblical story of the miracles of loaves. "Jesus Christ managed to divide two loaves of bread between several thousand people," Gruenbaum writes in his diary. "Two loaves and five fishes without having to use a cane, but according to the Gospel they were sated" (Glasner-Heled and Bar-On 2009, p. 6). Jarausch writes on 15 October 1941: "I was reminded how I had been so occupied before the war with the idea of the 'Christianity' and historical 'reality' of the miracle of the loaves. Feeding the hungry is truly a miracle that only God can perform" (Jarausch 2011, pp. 306-7). Both men seem to realize the absurdity of their duties. Giving out food puts them in a position of relative power, potentially saving or prolonging lives; but since there was never enough food, they became, like flawed and failing saviors, instruments of death. In intimate proximity to the stench of starving bodies they witness abominable horrors that they rather not put into writing. "I will not recount common occurrences [like] eating human flesh," Gruenbaum writes (Glasner-Heled and Bar-On 2009, p. 8).

We do not know why Gruenbaum referenced the miracle of Jesus-he does not further comment on it - though we suspect it to be an expression of angry, sarcastic sorrow. For Jarausch, Jesus' miracle of the loaves challenged his Christian moral values. In a letter a few days later, he alludes to a line from the gospel of Matthew 25:42, "for I was hungry and you gave me food." He writes: "I can't stop thinking about this passage. I am trying to do what I can do. It's not much in the face of the worst suffering I've ever encountered in my life ... [T] he question is simple: who is your neighbor?" (Jarausch 2011, p. 308).

\section{Acting and Witnessing in the Gray Zone}

The words of Jarausch and Gruenbaum are preserved in the form of intimate testimonies. In the personal letters and the diary fragments, we see two men struggling with who they are and the choices they made in circumstances not of their volition. In their writings, they are both actors and witnesses. As actors, they find themselves in positions of relative power that grants them some privileges but only limited control. As witnesses, they lament the horrors playing out in front of their eyes: the degradation of fellow humans to near-vegetative states due to intentional starvation policies. Though they wish to help, they become managers of death. They operate in the gray zone.

Part of the perfidiousness of the Nazi system of persecution and annihilation was to implicate Jewish people in their own destruction as Primo Levi described it with such agonizing accuracy. Assigning administrative duties to individuals in exchange for limited privileges (promises to protect their families from deportation, extra food, clothing, shelter, etc.), prison functionaries compromised their morality to the point of culpability. Those included the Jewish elders and police in the ghettos and, in the camps, bloc elders, kapos, doctors, and the Sonderkommando ${ }^{17}$ National Socialism thus shifted "onto othersspecifically the victims - the burden of guilt, so that they were deprived of even the solace of innocence," Levi writes in The Drowned and the Saved (Levi 1989, p. 53).

16 Glasner-Heled and Bar-On come to a similar conclusion: "Should we accept Gruenbaum as a first-hand witness? Does he report about hunger as one who has experienced it himself? No. It seems, rather, that he has sensitively described the hunger of others which he has witnessed" (Glasner-Heled and Bar-On 2009, p. 20).

17 From those positions, Levi distinguishes low-ranking functionaries, like kettle-washers, watchmen, lice checkers, messengers, and bed smoothers, who "worked full time like everyone else but for an extra half-liter of soup" and who were "rarely violent" (Levi 1989, p. 44). 
Gruenbaum belonged to the group of privileged Jews who survived, at least in part, because they used their positions at the cost of other Jewish lives. In his efforts to present himself as an observer and interpreter of events in Birkenau, Gruenbaum failed to reflect on the limited privileges he had as kapo. ${ }^{18}$ Levi has harsh words for such collaborators: "the worst survived, the selfish, the violent, the insensitive ... the fittest" (Levi 1989, p. 82; also Brown 2013, chapter 1). They deserve "a quota of guilt," Levi states, then hastens to add that "no one is authorized to judge them, not those who lived through the experience of the Lager [camp] and even less those who did not" (Levi 1989, pp. 49, 59). Nevertheless, Gruenbaum remained forever marked and had to defend himself against accusations as a collaborator at various formal and informal trials after the war.

Jarausch's letters put the German reserve officer also into the gray zone, though as a member of the nation of perpetrators. ${ }^{19}$ Philosopher Claudia Card refers to gray zones as the "result from choices that are neither gratuitously nor willfully evil but nevertheless implicate choosers in perpetrating, sustaining, or aggravating evils" (Card 1999, p. 14). ${ }^{20}$ Though initially not opposed to the war, Jarausch came to recognize the humanity of those he guarded, fed, and watched as they starved or froze to death. His options, he felt at the time, were limited. In his mind, he tried to do the best within an impossible situation. Despite his moral misgivings nurtured by religion, he did not resist the dictates of the military.

It would be wrong, of course, to claim that both men were similarly confined. Jarausch had access to the structures of power, food, small luxuries, leisure time, and letter writing, all of which allowed him to step back from the worst excesses of violence against people that his nation declared enemies. Gruenbaum had little room to maneuver and was granted only the smallest necessities to keep him alive in return for enforcing violence against his own people.

As regard their acts of witnessing the effects of extreme hunger, both men took on the same vantage point: they saw the misery lined up in front of their cauldrons. They kept order with their available means of enforcement, lamented their inability to help in meaningful ways, and zoomed in on particular incidents with pained sensitivity and empathy. Their descriptions of the starvation they witnessed do not differ much-to the point that both the Jewish Communist inmate in Birkenau and the Protestant German soldier in Belarus refer to the story of Jesus' miraculous feeding of the hungry, a story that stands in sharp contrast to their inability to alleviate suffering. Through their eyes and words, we begin to recognize the abject misery caused by extreme hunger.

As regards their actions, they differ greatly. Although Jarausch can be described as a casualty of an ideological war to which he was conscripted and which he grew to question, he was not a victim. He acted as a soldier. He beat Soviet prisoners. He may have shot Soviet prisoners. He may have unmindfully exploited them as conversation partners and language teachers. But he also formed bonds with Russian POWs, assisted where he could, and came to acknowledge their humanity. In the process, he put himself increasingly at risk. Gruenbaum was a victim but also a collaborator within a system that aimed to annihilate him. He became a kapo. He beat fellow prisoners. He did everything to survive, even at the cost of sacrificing his previous values of protecting the weak. But he was also instrumental in the underground resistance in Auschwitz. According to some witnesses, he assisted fellow prisoners within the unforgiving universe of the camp.

18 Glasner-Heled and Bar-On offer similar critical insights into Gruenbaum's self-presentation (Glasner-Heled and Bar-On 2009, esp. 20-21).

19 Levi is extremely hesitant to consider German perpetrators operating in their own gray zone, but cautiously opens a door for such a possibility in reference to a small human gesture by an SS man, placing him at the "extreme boundary" of the gray "zone of ambiguity" (Levi 1989, p. 58).

20 Sander Lee would argue against such broadening of the concept of the gray zone on the grounds of her post-Holocaust ethics. "My primary purpose," she states in her conclusion, "has been to argue that Primo Levi's term gray zone should be reserved for the purpose for which he intended it" (Lee 2016, p. 294). 


\section{Death}

There is almost a reverse arc: the nationalist Protestant German who welcomed, with reservations, the rise of Hitler moved from complicity with Nazism to an increasingly critical stance vis-à-vis the human cost of war. The Polish-Jewish Communist started with resistance to nationalism and fascism and ended up in a position that made him complicit with the Nazi regime.

On 26 August 1941, Jarausch writes to his mother that he hopes to "survive Russia." He adds: "I am afraid of lice because of the close contact with prisoners" (Jarausch 2011, p. 269). Despite his fear of lice, in the coming months he will closely interact with Russians, not just during food distribution but also socially. On 8 January 1942, he writes that he needs to forcefully maintain order in the kitchen: "My right hand is swollen from all the blows I dispense." Two sentences later, he continues, "I now have a new translator; he's a geography teacher at a school in Moscow" (361). A letter he pens to his wife on 13 January 1942 reads: "May God bless our wishes for the future. Everything now is in His hands. Here it's horribly cold" (364). Two weeks later, Konrad Jarausch is dead. He died of typhoid fever transmitted by lice. A typhoid epidemic was at the time spreading among Russian POWs.

When Gruenbaum failed to get solid ground under his feet in Europe, he relented to his father's pleas to come to Israel. He arrived in Jerusalem in May 1946. Suspicion followed him despite Yitzhak's best efforts to rehabilitate his son. Eliezer Gruenbaum enlisted in the Yishuv's armed forces. Though turned down at first, his father's contacts finally got him enlisted in the Jerusalem People's Guard Reserve. Shortly after, he participated in the battle at Ramat Rachel in May 1948, a kibbutz near Jerusalem. On May 22, Eliezer Gruenbaum died from gunshot wounds in combat with Arab forces. Rumors soon spread that he had been shot by fellow Jews in revenge for his deeds as a kapo. Those rumors persisted but could never be verified. ${ }^{21}$

Other tragic events surrounded their deaths. Shortly after arriving in Jerusalem, Gruenbaum fell in love with Stefa Rosenzweig. When Stefa heard the news of his death at Ramat Rachel, she killed herself. ${ }^{22}$ Konrad Jarausch heard about the birth of his son in Kochanova. On 23 October 1941, he writes to his wife: "My situation is like yours. You have to take care of your child, and I have to take care of more than 11,000" (Jarausch 2011, p. 307). He will never get to see his son. And the son, Konrad H. Jarausch, will grow up "in a dead father's shadow in postwar Germany" (vii) and, decades later, edit and publish his father's letters.

\section{Ethical Loneliness and the Public}

The intimacy of the genre-personal letters and a diary—should not distract us from the public audience these writings were seeking. That any of Gruenbaum's diary pages are available is not accidental but the result of an ambitious father who went out of his way (and risking his reputation as a leader in the Yishuv) to rehabilitate his son. What we have, in the words of Glasner-Heled and Bar-On, is a "memoir fragment" (Glasner-Heled and Bar-On 2009, p. 4) that saw the light of publication only because his father lobbied for it after Gruenbaum's death. The diary selections were eventually included in a literary anthology of Israelis who fell in battle, though Gruenbaum's writing did not match the style of the other contributions in the Scrolls of Fire. The anthology's editor and other people objected to including Gruenbaum's diaries because they did not want to give a public forum to a former kapo. Yitzhak eventually prevailed. ${ }^{23}$ In a further twist, a character in one of Yehiel De-Nur's novels (the well-known survivor writing under the name of Ka-Tzetnik) was based on Gruenbaum. In Ka-Tzetnik's They Called Him Piepl, a kapo in

21 Friling painstakingly sifts through the evidence and concludes that the "question of how Eliezer was killed" cannot be decided (Friling 2014, p. 197).

22 For more details, see Friling (2014, chapters 11 and 12).

23 On this controversy, see Friling (2014, chapter 13). According to Glasner-Heled and Bar-On (2009) and Friling (2014), the Gruenbaum family never granted access to Eliezer's complete diary; it is possible that by now it is lost. 
Auschwitz Birkenau named Prochtenbaum brutalizes pious Jews. When Ka-Tzetnik was asked whether his fictional character was based on Gruenbaum, he answered that the Prochtenbaums in his novel, "both the father, the eminent Zionist leader, and the son as well, are part of factual reality" (Friling 2014, p. 206) ${ }^{24}$

Gruenbaum's diary fragment, hence, is not only an intimate testimony but also marred by public and behind-the-scenes controversy. As readers, we might be torn between, on the one hand, the "fragile corporeality" (Mandel 2006, p. 24) of Gruenbaum himself and his fellow prisoners and, on the other, the exculpation that the diary's publication may have sought. We thus enter into a complicity which, according to Mandel, is the condition for ethical engagement. Being affected as a reader by the harrowing descriptions of starving prisoners, we may cherish Gruenbaum's diary as a cri de coeur, as a kind of confessional unburdening of the former kapo's soul. But what if the publication was an attempt at justifying himself in the eyes of the public? Does Gruenbaum, like his father, try to rehabilitate himself within the Jewish community? This is a reasonable assumption given that Jewish Honor Courts set up across Europe immediately after the war and later the so-called kapo trials in Israel went after accused Jewish collaborators in the ghettos and camps (Porat 2019; Jokusch and Finder 2015). Historian Friling reads Gruenbaum's diaries as a "defiant and candid" text, with him "ably and defiantly" defending himself. "This was not apologetics" (Friling 2014, p. 182). Glasner-Heled and Bar-On, both trained in psychology, present a nuanced and sympathetic view. They suggest that "contemporary readers can respond with empathy and less judgment than did those who encountered Gruenbaum's text when it first appeared" (Glasner-Heled and Bar-On 2009, p. 2). If we adopt Mandel's suggestion to understand complicity as part of the structure of the Lager rather than a "charge (like collaboration) or a verdict (like culpability)" (Mandel 2006, p. 216), then Gruenbaum was complicit. But was he also culpable? Contemplating such a judgment makes us, as readers, inevitably complicit in a situation that calls us into responsibility and challenges our empathetic imagination.

Was Gruenbaum suffering from ethical loneliness? "Ethical loneliness," philosopher Jill Stauffer states, "is the isolation ... a violated person" feels when "one has been abandoned by humanity ... It is a condition undergone by persons who have been unjustly treated and dehumanized by human beings and political structures" (Stauffer 2015, p. 1). The unnamed prisoners in the food lines in Birkenau and the Dulag must have felt such loneliness in their abandonment. But would people operating in the gray zone also suffer from ethical loneliness? Gruenbaum himself speaks in his diary of the great "solitude" that prisoners experienced in Birkenau as they were awaiting death, a solitude that was, according to him, intentionally manufactured by the Nazis (Glasner-Heled and Bar-On 2009 , p. 11). Others described Gruenbaum himself as a "figure of great solitude who has fallen between the worlds" (2). Having been abandoned by the world when he entered Auschwitz, having witnessed the abandonment of starving prisoners, being abandoned after the war by many of his political comrades and the Israeli public, and being denied the "solace of innocence" (Levi 1989, p. 53), we must imagine Eliezer Gruenbaum trapped in ethical loneliness. His diary may have been his attempt at breaking through his loneliness to communicate with a non-comprehending public.

Ethical loneliness does not, however, apply to Konrad Jarausch. For him, letter writing was a form of communication across a war-ridden continent. He spoke frankly and openly despite military censorship (though he remained guarded and sparse about the murder of Jews). He wrote his letters with an awareness that they might be of public interest. According to his son, "he asked that his letter be preserved" (Jarausch 2011, p. 22). Jarausch's introspective and teacherly manners may have isolated him within his military unit, but he was not lonely. Haunting, however, might be a good way to describe the legacy he left, a legacy quite familiar among descendants of German families that have

24 According to Friling (2014), Gruenbaum's brother Yonatan Gruenbaum defended Eliezer and their father against these accusations in an unpublished manuscript. 
been complicit with the Nazi regime, ranging from compliance to culpability (Schwab 2010; Krondorfer 2020, pp. 137-49). "The missing father who had died in Russia in January 1942," his son writes in the introduction, "hovered like a phantom over my entire childhood" (Jarausch 2011, p. 1).

\section{Closing Remarks}

"To be haunted," Mandel writes, "is to eschew the moral high ground that the unspeakable so seductively supplies and to embrace the complicity of our own situation in structures of violence and power" (Mandel 2006, p. 23). The ambiguities with which we are left when engaging empathetically and critically with the testimonies of Jarausch and Gruenbaum may be haunting in their own ways. We cannot judge these two men based solely on the few glimpses of their lives presented here. But they tell us something about testimonial limits in the gray zone. Gruenbaum and Jarausch moved in an ambiguous zone that was marked by complicity and empathy. Complicity manifested itself in their actions over which they had limited control; empathy, however sparse, expressed itself in their witnessing of starving people, which they preserved in their writings.

Testing testimonial limits in such circumstances takes us, as readers, to the ambiguous space of judgment and empathy. The writings of Jarausch and Gruenbaum are our entry points to recognize extreme hunger for what it is: starving people to death robs them of the last ounce of their moral core. It reduces a human being to plucking from a dying man's "mouth a half-chewed piece of bread mixed with froth" (Glasner-Heled and Bar-On 2009, p. 7). Our judgment is imperative when calling out the depravity of a system that organizes the evil of intentional starvation. Our empathy is required when recognizing the utter abandonment and loneliness of people subjected to such evil. And somewhere in between, we need to wrestle with the gray zone of complicity that Gruenbaum and Jarausch had to navigate.

Funding: This research received no external funding.

Institutional Review Board Statement: Not applicable.

Informed Consent Statement: Not applicable.

Conflicts of Interest: The author declares no conflict of interest.

\section{References}

Agamben, Giorgio. 1999. Remnants of Auschwitz: The Witness and the Archive. New York: Zone Books.

Becker, Michael, and Dennis Bock. 2020. Muselmänner in Nazi Concentration Camps: Thinking Masculinity at the Extremes. In The Holocaust and Masculinities: Critical Inquiries into the Absence and Presence of Men. Edited by Björn Krondorfer and Ovidiu Creanga. Albany: SUNY Press, pp. 129-46.

Brown, Adam. 2013. Judging "Privileged" Jews: Holocaust, Ethics, Representation and the "Grey Zone". New York: Berghahn.

Card, Claudia. 1999. Groping Through Gray Zones. In On Feminist Ethics and Politics. Edited by Claudia Card. Lawrence: University Press of Kansas, pp. 3-26.

Friling, Tuvia. 2014. A Jewish Kapo in Auschwitz: History, Memory, and the Politics of Survival. Waltham: Brandeis University Press.

Glasner-Heled, Galia, and Dan Bar-On. 2009. Displaced: The Memoir of Eliezer Gruenbaum, Kapo at Birkenau-Translation and Commentary. Shofar: An Interdisciplinary Journal of Jewish Studies 27: 1-23. [CrossRef]

Glowacka, Dorota. 2012. Disappearing Traces: Holocaust Testimonials, Ethics, and Aesthetics. Seattle and London: University of Washington Press.

Jarausch, Konrad H. 2011. Reluctant Accomplice: A Wehrmacht Soldier's Letters from the Eastern Front. Princeton: Princeton University Press.

Jokusch, Laura, and Gabriel Finder, eds. 2015. Jewish Honor Courts: Revenge, Retribution, and Reconciliation in Europe and Israel after the Holocaust. Detroit: Wayne State University Press.

Krondorfer, Björn. 2020. Unsettling Empathy: Working with Groups in Conflict. London and New York: Rowman \& Littlefield.

Krondorfer, Björn. 2006. Nationalsozialismus und Holocaust in Autobiographien protestantischer Theologen. In Mit Blick auf die Täter: Fragen an die Deutsche Theologie nach 1945. Edited by Björn Krondorfer, Katharina von Kellenbach and Norbert Reck. Gütersloh: Gütersloher Verlagshaus, pp. 23-170.

Lee, Sander. 2016. Primo Levi's Gray Zone: Implications for Post-Holocaust Ethics. Holocaust and Genocide Studies 30: 276-97. [CrossRef] Levi, Primo. 1989. The Drowned and the Saved. New York: Vintage. 
Mandel, Naomi. 2006. Against the Unspeakable: Complicity, the Holocaust and Slavery in America. Charlottesville: University of Virginia Press.

Peri, Alexis. 2017. The War Within: Diaries from the Siege of Leningrad. Cambridge: Harvard University Press.

Petropolous, Jonathan, and John K. Roth, eds. 2005. Gray Zones: Ambiguity and Compromise in the Holocaust and Its Aftermath. New York: Berghahn.

Porat, Dan. 2019. Bitter Reckoning: Israel Tries Holocaust Survivors as Nazi Collaborators. Cambridge: The Belknap Press of Harvard University Press.

Rothberg, Michael. 2019. The Implicated Subject: Beyond Victims and Perpetrators. Stanford: Stanford University Press.

Schwab, Gabriele. 2010. Haunting Legacies: Violent Histories and Transgenerational Trauma. New York: Columbia University Press.

Stauffer, Jill. 2015. Ethical Loneliness: The Injustice of Not Being Heard. New York: Columbia University Press. 